\title{
Comparison of bacterial communities in roots of selected trees with and without summer truffle (Tuber aestivum) ectomycorrhiza
}

\author{
Marta Siebyta $^{1}$, Iwona Szyp-Borowska ${ }^{2}$ \\ ${ }^{1}$ Forest Research Institute, Department of Scientific Information and Promotion, Braci Leśnej 3, 05-090 Raszyn, Poland, \\ e-mail: m.siebyla@ibles.waw.pl \\ ${ }^{2}$ Forest Research Institute, Department of Silviculture and Genetics of Forest Trees, Braci Leśnej 3, 05-090 Raszyn, Poland
}

\section{Abstract}

In this study, we examined the effect of the presence of mycorrhiza and ascomata of summer truffle (Tuber aestivum) on the bacterial composition of roots from small trees growing in selected sites of the Nida Basin. Qualitative DNA sequencing methods such as Sanger and next-generation sequencing (NGS) were used.

The Sanger method revealed different bacterial species compositions between the samples where summer truffle ascomata was recorded and control samples. Five genera of bacteria could be distinguished: Bacillus, Erwinia, Pseudomonas, Rahnella and Serratia, among which the most numerous were Pseudomonas (Gammmaproteobacteria class) at $32.9 \%$. The results obtained by the NGS method also showed differences in species composition of the bacteria depending on the study sample. Seven genera of bacteria were distinguished: Rhizorhabdus, Methylotenera, Sphingomonas, Nitrosospira, Streptomyces, Methyloceanibacter and Niastella, which dominated in roots from the truffle sites. Telmatobacter, Roseiarcus, Granulicella, Paludibaculum, Acidipila, Acidisphaera and Aliidongia dominated in roots from the control sites. With the NGS method, it is possible to identify the microbiome of a whole root, while only a root fragment can be analysed by the Sanger method.

These results extend the scope of knowledge on the preferences of certain groups of bacteria associated with truffles and their influence on the formation of ascomata in summer truffles. Our results may also be useful in selecting and monitoring sites that promote ascomata of Tuber aestivum.

\section{KeY WORDS}

mycorrhiza, NGS, soil microorganisms, summer truffle ascomata, roots

\section{INTRODUCTION}

Due to its physical properties and chemical composition, the soil is a suitable environment for the development of microorganisms, especially bacteria and fungi.
Their biological activity affects, among other things, the fertility of the soil, as well as the availability to plants of nutrients derived from the decomposition of the biomass by microorganisms (Galus-Barchan and Paśmionka 2014; Pociejowska et al. 2014). Depending 
on environmental factors, the quantitative and qualitative composition of microorganisms may vary over time. Differences in bacterial counts may also result from their populations' diversity, sometimes even within one site (Clark 1971; Steinauer et al. 2016).

The layer of soil most populated by microorganisms is the rhizosphere. This layer contains several to several hundred times more bacteria than the soil zone outside the rhizosphere. Foster (1988) states that in one gram of dry matter within the rhizosphere, there are $10^{10}-10^{12}$ bacterial cells, and outside it, no more than $10^{8}$ cells per gram of soil. In the rhizosphere, there are microorganisms with a different qualitative composition than in soil without plants. The relationships between microbes and plants are complex. Bacteria and fungi living in the rhizosphere are dependent on hosts (plant roots), nutrients, other microbial populations and climatic conditions that stimulate or inhibit their diversity (Bardgett 2011; Lau and Lennon 2011; Eisenhauer et al. 2017).

A diversified microbiome can be observed in the roots of plants. The plant's condition is strongly influenced by the microbial community, which in turn is influenced by the host (Beckers et al. 2017; Proenca et al. 2017). This microbiome is made up of microorganisms that have a beneficial (plant growth-promoting rhizobacteria, PGPR), neutral (neutral rhizobacteria) or deleterious (deleterious rhizosphere microorganisms, DRMO) effect on plant development (Kurek and Kobus 1990). Symbiosis is one example of the beneficial influence of microorganisms on plant development.

It is well known that through symbiosis, organisms acquire capabilities and properties that they would not otherwise show (Frey-Klett et al. 2011). The Poole study (2001) shows that the rhizosphere layer is dominated by bacterial species belonging primarily to the genera Pseudomonas and Bacillus, which have beneficial influences on the plant, such as increasing its health and reducing potential infections (Badura 2005). These are free-living bacteria that mineralize organic compounds and fix molecular nitrogen. Soil bacteria that symbiotically fix nitrogen are, for example, commonly found in legumes and include Rhizobium and Frankia (Błaszczyk 2010).

For many years, the direct influence of rhizospheric microorganisms on the stimulation of plant growth was associated with their ability to fix nitrogen. Rhizospheric bacteria have received particular attention because of their potential use in stimulating the colonization of mycorrhizal roots and, consequently, the industrial production of fungi, including truffles (Boersma et al. 2009, 2010; Antony-Babu et al. 2014). Free-living bacteria (PGPR) have a beneficial effect on plants by stimulating their growth directly and indirectly. Bacterial communities isolated from root secretions have shown an effect on stimulating the development of mycorrhizal mycelia (Ali and Jackson 1988). Some rhizospheric microorganisms can also induce changes in the quantity and composition of root secretions (Deveau et al. 2007). Direct support consists of stimulating mineral nutrition, for example, by facilitating the uptake of nitrogen, dissolving phosphorus compounds or binding iron by siderophores. This also includes the synthesis of phytohormones that affect plant development, that is, auxins, gibberellins and cytokinins, as well as lowering ethylene levels that affect plant rooting. Indirect support, on the other hand, is associated with bacterial-based biological control of phytopathogens. Bacteria can exhibit various symbiotic effects against fungi and also inhibit pathogen development through antagonism (Tsukamoto et al. 2002; Frey-Klett et al. 2007), improve spore distribution (Citterio et al. 1995; Splivallo et al. 2015), and provide vitamins and growth regulators (Rangel-Castro et al. 2002; Riedlinger et al. 2006).

Soil is inhabited not only by bacteria. It is also the natural habitat for fungi, including the genus Tuber from the division Ascomycota. Truffles (genus Tuber) are found, apart from North America and Asia, in many European countries including France, Italy, Spain and Poland as a natural component of forest ecosystems (Blom et al. 2011; Hilszczańska 2016). Truffles are colonized in all stages of their life cycle by various microorganisms including bacteria (Vahdatzadeh et al. 2015), Cryptococcus yeast (Zacchi et al. 2003), and moulds and viruses (Splivallo et al. 2015). Microorganisms accompany fungi/truffles in the symbiotic stage when they remain in an ectomycorrhizal relationship with the plant, as well as in the sexual stage (ascomata) and the saprotrophic stage (free-living mycelium). The development of truffle mycorrhiza, as well as the growth of bacteria, is regulated by temperature, humidity, structure and soil chemistry. Some microbes called mycorrhiza helper bacteria (MHB) stimulate mycorrhizal colonization of host roots and consequently affect the development of truffle ascomata (Gryndler et al. 2013). To date, 
the microbial communities best recognized are those that occur in the ascomata of the four truffle species appreciated in the kitchen: the white truffle (Tuber magnatum), the whitish truffle (T. borchii), the black truffle (T. melanosporum) and the summer truffle (T. aestivum) (Hilszczańska 2016; Siebyła and Hilszczańska 2020).

Research in many countries shows that the role of bacteria and fungi in the functioning of forest soils is not yet fully understood. This is especially true for the evaluation of bacterial diversity and their relationship with fungi (Baldrian et al. 2012), particularly regarding the summer truffle, in which communities of the coexisting bacteria were usually identified by the 454 method, PhyloChip (Gryndler and Hršelová 2012; Mello et al. 2013; Deveau et al. 2016). Nowadays, owing to the use of modern molecular methods such as next-generation sequencing (NGS), it is possible to get a thorough understanding of the composition of microbial communities that inhabit the roots, including those that are conducive to truffle growth (Gryndler et al. 2013).

This study aimed to elucidate the bacterial communities associated with the ascomata of the summer truffle T. aestivum found in selected locations in Poland. Two different methods were applied in this study: a) the classical method, that is, the plate culture method, which involves the identification of bacteria in samples from the roots at the sites where summer truffle ascomata are observed and in the samples where no summer truffle ascomata are observed, and b) the molecular method consisting of the isolation of DNA of both the Sanger and NGS methods. Sanger sequencing was used to identify the isolated bacteria based on DNA isolated from pure strains, and the NGS method was used to analyse the DNA isolated from roots.

It has been assumed that the 'truffle' sites will exhibit a specific composition of the bacterial microbiome, which may help monitor soils conducive to truffle development and yield.

\section{Material AND Methods}

\section{Research areas}

The research was conducted on three study sites within the Nida Basin, described as G, M and W (the abbreviations $\mathrm{G}, \mathrm{M}, \mathrm{W}$ come from area/location names). The research areas are located in forests (locations), which are at an altitude of 250 to $296 \mathrm{~m}$ above sea level on Rendsina soils. In each location, six research areas were designated: three in which summer truffle ascomata (variants T) were found (G1-3, M1-3, W1-3) and three control areas, where no summer truffle ascomata (variants C) were found (G4-6, M4-6 W4-6) (Siebyla and Hilszczańska 2020). For the analysis of bacterial communities, samples of fine roots with a diameter of $\sim 1 \mathrm{~mm}$ with ectomycorrhiza visible to the naked eye were taken from a depth of $10-15 \mathrm{~cm}$ in spring and autumn of 2017 and 2018. A total of 72 samples were collected, 18 in spring and 18 in autumn each year. Root samples were taken from research areas where summer truffle ascomata had been recorded in the previous years (Rosa-Gruszecka et al. 2014; Hilszczańska 2016; Hilszczańska et al. 2019).

The occurrence of the dominant tree species in individual samples taken from all the areas, as well as information about the parent rock, are presented in Siebyla and Hilszczańska (2020). The root samples included: Tilia cordata Mill., Carpinus betulus L. and Quercus robur L. in samples from GT1-GT3; Corylus avellana $\mathrm{L}$. and $C$. betulus in samples from GC4, GC6 and GC5; Fagus sylvatica L. and C. avellana in samples from MT1 and MT2, MT3; C. avellana in samples from MC4-MC6; C. betulus and C. avellana in samples from WT1, WT2 and WT3; and C. avellana and C. betulus in samples from WC4 and WC5, WC6, respectively.

\section{Microbiological analyses of bacterial communities from roots}

Analyses of the diversity of bacterial communities were carried out using classical and molecular methods. Bacteria were cultured in pure cultures on agar medium imitating the natural environment, followed by the identification of strains according to the methods presented below.

Quantitative analysis - classical method

Quantitative analysis (measuring the bacterial count) performed by culture methods began with sterilization of the root samples in $70 \%$ ethyl alcohol for $3 \mathrm{~min}$, then in $2.5 \%$ sodium hypochlorite $(\mathrm{NaOCl})$ for $5 \mathrm{~min}$, then again in $70 \%$ ethyl alcohol for 30 seconds. After sterilization, the roots were rinsed 5 times with distilled water and dried (Sun et al. 2008; Kubiak et al. 2017). The roots were then cut in sterile conditions into 
$0.5 \times 0.5 \mathrm{~cm} \times 0.5 \mathrm{~cm}$ fragments. Seven fragments were laid out on each plate with a culture medium (with nutrient broth) (Gotkowska-Płachta et al. 2008). Two replicates were made for each soil sample. The control for the study was water kept from the last root rinsing. The cultures were incubated for 5 days at room temperature. The number of new colonies was recorded every day and after the determined number of days, the total number of colonies was recorded (Colony Forming Units $-\mathrm{CFU})$.

Qualitative analysis - molecular method

In order to perform qualitative analyses, material was used from a single bacterial colony, obtained by means of streaking and multiplied in a liquid medium of nutrient broth. The DNA extraction was carried out according to the instructions provided with the bacterial isolation kit: Bacterial Genomic Miniprep Kit Sigma Aldrich (Merc Germany) and the isolated product was then amplified using the Polymerase Chain Reaction (PCR) method. The PCR reaction was performed according to the following protocol: pre-denaturation at $94^{\circ} \mathrm{C}$ for 4 min; amplification - 30 cycles, denaturation at $94^{\circ} \mathrm{C}$ for $60 \mathrm{~s}$, annealing of primers at $62^{\circ} \mathrm{C}$ for $40 \mathrm{~s}$, the extension of the primer at $72^{\circ} \mathrm{C}$ for $2 \mathrm{~min}$ and elongation at $72^{\circ} \mathrm{C}$ for $6 \mathrm{~min}$. Amplifications were performed in $10 \mu \mathrm{l}$ with $1 \mu \mathrm{l}$ DNA, $0.2 \mathrm{U} / \mu \mathrm{l}$ Taq polymerase (Qiagen), $1 \mu 1$ 10X buffer PCR (Qiagen), $1.5 \mathrm{~mm} \mathrm{Mg} \mathrm{(25} \mathrm{mm)}$ (Qiagen), $0.1 \mathrm{~mm}$ dNTP (5 mm) (Qiagen), $0.1 \mu \mathrm{l}$ each primer $(10 \mu \mathrm{m}), 5 \mu 125 \times$ buffer Q (Qiagen). The universal bacterial domain primers were used for the PCR reaction: 530f (5'GTG CCA GCM GCC GCG G'3) and 1100R (5'GGGTTGCGCTCGTTG'3) (Lane 1991; Gryndler et al. 2013).

The products were cleaned using a Clean-up kit (from A\&A Biotechnology). The PCR products were sequenced using the Sanger method (Tedersoo et al. 2010). The analysis was carried out by Genomed S.A., Warsaw, Poland. Finch TV software was used to analyse the sequencing products. The obtained sequences were compared with the NCBI Gene Bank database using Blast (http://www.ncbi.nlm.nih.gov).

\section{Meteorological data}

Temperature and hydrological data for the nearest measuring stations Kielce and Cracow were recorded on the basis of monthly Bulletins of the State Hydro- logical and Meteorological Service of the Institute of Meteorology and Water Management (IMGW-PIB). Using these values, Sielianinov's hydrothermal coefficient $K$ for the years 2016-2018 was calculated $(K=P \times 10 / \Sigma \mathrm{t})$, where $P$ is the sum of precipitation and $\Sigma \mathrm{t}$ is the sum of average temperatures during the vegetation period). Coefficient $K$ values are as follows: $0-0.4$, extremely dry; $0.41-0.70$, very dry; 0.71-1.0, quite dry; 1.1-1.3, dry; 1.31-1.6, optimal; 1.61-2.0, moist; 2.1-2.5, wet; $>2.5$, very wet (Sosnowski and Król 2018; Siebyła and Hilszczańska 2020).

\section{Metagenomic analysis of DNA samples}

In 2018, DNA was isolated directly from the roots of the tree species tested, both in Tuber (T) and control (C) variants, and used for NGS sequencing and metagenome analysis based on the 16S RNA fragment (bacterial composition). Amplicon sequencing included the V3-V4 fragment of the 16S rRNA gene enabling the analysis of taxonomic groups of bacteria. Amplicons were prepared using samples of isolated DNA obtained by PCR and $16 \mathrm{~S}$ libraries. Sequencing was performed using Illumina's MiSeq in two reads of 300 base pairs. The expected mean number of reads per sample was 160,000-180,000. The bioinformatic analysis included filtering of the reads and analysis of the sample composition for each taxonomic category based on database homologues (Medinger et al. 2010; Staley et al. 2013).

\section{Indicators of genetic and biological diversity}

Indicators of genetic and biological diversity were calculated on the basis of: a) alpha biodiversity of samples representing a given community (applied to individual communities within a specific delimited area, which was determined by a collective list of species occurring within a given geographical unit) and b) beta diversity determining species diversity when comparing communities (Kim et al. 2017).

Alpha biodiversity was determined on the basis of the diversity of identified operational taxonomic unit (OTU) sequences within a biological sample. The alpha biodiversity indices were determined by the biodiversity indices, that is,, Chao's index, Faith's phylogenetic diversity, observed OTUs, number of distinct features, Heip's evenness measure, and Shannon's and Simpson's indices. The alpha biodiversity indices were calculated 
using Qiime2 software with the implemented alpha diversity, alpha-phylogenetic diversity, and alpha group significance diversity programs. All the samples, divided into individual groups as described above, were used for analysis. A detailed description of the indices can be found in Siebyła and Hilszczańska (2020).

Beta biodiversity determines the diversity of the identified OTU sequences within a given group of biological samples. Beta biodiversity was defined by biodiversity indicators, that is, unweighted and weighted UniFrac, Bray-Curtis dissimilarity (a measure of similarity between samples, referred to as semimetric), and Jaccard index. A detailed description of the indices can be found in Siebyła and Hilszczańska (2020).

\section{Statistical analyses}

All the tested groups of bacteria, depending on the biodiversity indicator used, were assessed with the KruskalWallis non-parametric test, with the null hypothesis assuming an equal number of species in the group. The UniFrac measures used to determine beta biodiversity were calculated using the Qiime2 software with its implemented diversity core-metrics-phylogenetic program (Lozupone and Knight, 2005). As a result of the analysis, PcoA plots were prepared, illustrating the distances (differences in sequences) between individual groups of samples. The PcoA plots were prepared using R software (Team 2013). Analyses of the beta biodiversity results was performed using Qiime2 software with the implemented diversity beta-group-significance program. The PERMANOVA test, which determines the differences in distances between groups, was also used in the analysis.

\section{Analysis of alpha and beta correlations with $C R$ (Colonisation Root) coefficient values}

The analysis of the correlation of alpha and beta biodiversity results was performed using Qiime2 software with the implemented diversity alpha-group-significance and diversity beta-group-significance programs. The plots for the alpha correlations were made using $\mathrm{R}$ software, preceded by the evaluation of the normality of the distribution using the Shapiro-Wilk test. Spearman's rank correlation coefficient (non-parametric test, for data without normal distribution) and Pearson correlation coefficient (parametric test for data with normal distribution) were used in the analyses. All the alpha and beta biodiversity indicators were calculated for 4 factors: spring 2017, spring 2018, autumn 2017 and autumn 2018.

\section{Results}

\section{Quantitative analysis}

The root colonization by bacteria assessed based on the CR coefficient expressed as a percentage was more varied in 2017 than in 2018. In 2018, regardless of the season, the root colonization coefficient value was $\sim 1.0$ for samples from all three areas, while in 2017, the root colonization coefficient ranged from 0.5 to 1.1. In spring, the lowest value of the root colonization coefficient was recorded on the surface of G6 (0.5\%) and the highest on the surface of M2 $(1.1 \%)$. In the case of the assessment in autumn 2017, the lowest value of the coefficient was characterized by the surface of W3 $(0.5 \%)$ and the highest, equal to 1 , by surfaces M2, M4, M5, M6 and W4.

In area $\mathrm{M}$ in autumn 2017, the degree (\%) of root colonization (CR) by bacteria was similar to that of 2018. A similar situation was recorded in area $\mathrm{W}$ in autumn 2017, except for sample W3, where the colonization coefficient was $\sim 0.5$. An inverse situation was recorded in area G (autumn 2017), where the colonization coefficient was $0.65-1.0$ in the truffle variant (T) and $0.65-0.8$ in the control variant $(\mathrm{C})$. The average value of the root colonization coefficient in spring 2017 was similar regardless of the location (Fig. 1). The root colonization coefficient (CR) in area $\mathrm{G}$, regardless of the season, did not exceed $0.8 \%$ on average. The exceptions were the samples from G1, G2, where the coefficient was equal to $\sim 1.0$. The lowest value of the root colonization coefficient was recorded in spring in the truffle variant $(\mathrm{T})$ for sample $\mathrm{G} 3$ with a value of $\sim 0.2$ (Fig. 1).

The uniform degree of root colonization in 2018 could have been affected by meteorological conditions, regardless of the season and location (Tab. 1). The value of hydrothermal coefficient $K$ in 2017 was optimal for vegetation at the level of 2.11-2.27, while in 2018, it was unfavourable in the range of $0.95-1.25$. Similar differences were noted for total precipitation. In 2017, the total precipitation was $\sim 540 \mathrm{~mm}$, and in 2018 , it ranged from 340.10 to $459.00 \mathrm{~mm}$. 


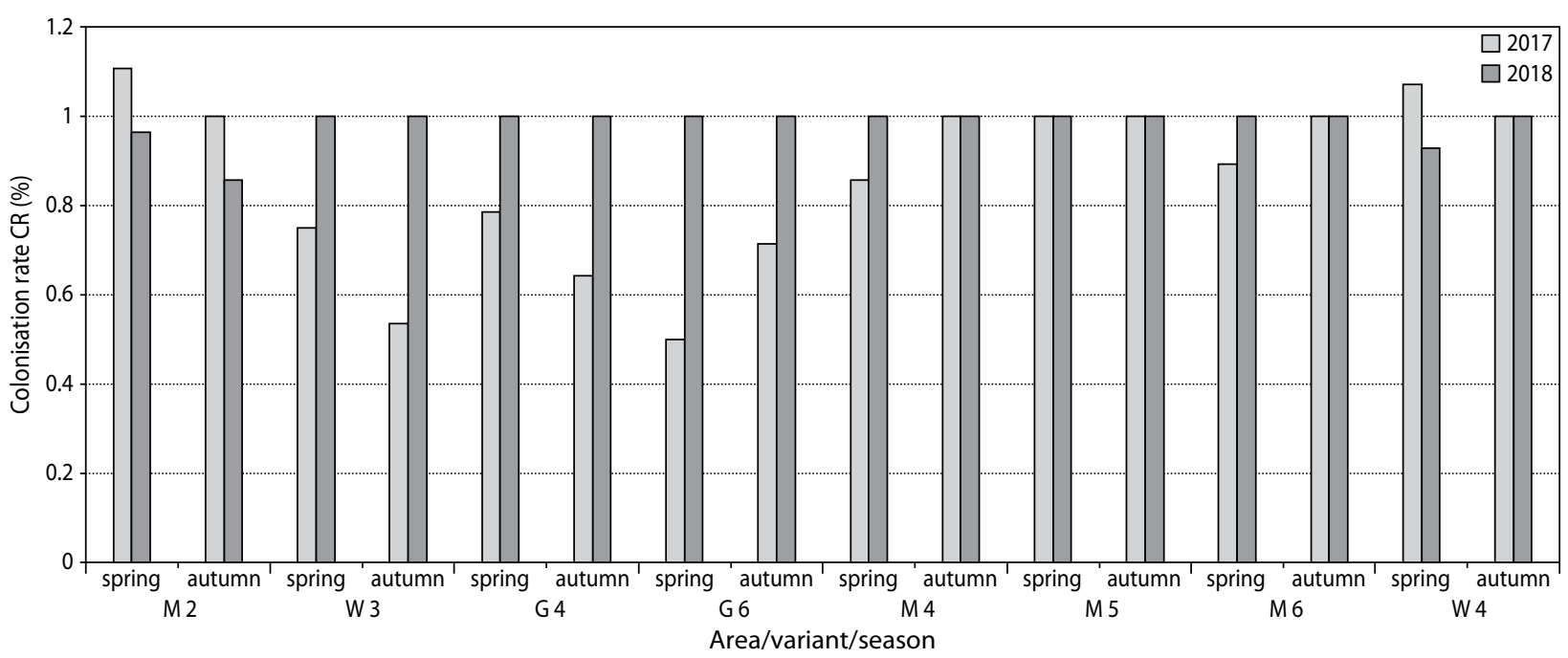

Figure 1. Degree of root colonization expressed in \% by bacteria, taking into account the research area (G, M, W), the variant $(2,3,4,5,6)$, the season (autumn, spring) and year of evaluation $(2017,2018)$ for samples taken from Corylus avellana roots

Table 1. Average values of hydrothermal coefficient $K$ and the average sum of precipitation for months IV-X at the nearest measuring stations in Kielce and Cracow in 2016-2018

\begin{tabular}{|l|c|c|c|c|}
\hline \multirow{2}{*}{$\begin{array}{c}\text { Station } \\
\text { name }\end{array}$} & \multirow{2}{*}{$\mathrm{K}$} & \multicolumn{2}{|c|}{ Total precipitation by month } & \multirow{2}{*}{ Years } \\
\cline { 3 - 4 } & & IV-X & I-XII & \\
\hline Kielce & 1.44 & 378.6 & 619.5 & \multirow{2}{*}{2016} \\
\hline Cracow & 1.95 & 553.6 & 745.3 & \\
\hline Kielce & 2.27 & 548.9 & 731.8 & \multirow{2}{*}{2017} \\
\hline Cracow & 2.11 & 545.9 & 702.3 & \\
\hline Kielce & 0.95 & 340.1 & 486.7 & \multirow{2}{*}{2018} \\
\hline Cracow & 1.25 & 459.0 & 568.7 & \\
\hline
\end{tabular}

\section{Qualitative analysis}

Of the 189 bacterial isolates from a single bacterial colony sampled between 2017 and 2018 in all the assessment variants, $14.3 \%$ of bacteria were no longer bred, while the remaining $85.7 \%$ were used for further molecular analyses. As a result of Sanger DNA sequencing, seven genera of bacteria were distinguished in the samples collected from areas G, M, W.

The most numerous bacteria recorded were those of the genus Pseudomonas (Gammmaproteobacteria class) isolated from the roots in spring and autumn 2017 and autumn 2018. The genera Rahnella and Serratia were equally numerous, but they were only recorded in spring 2018. In 2017, the genus Bacillus occurred at the same level of $6.8 \%$, while in 2018 , in the autumn, it was more than twice as numerous as in spring (Tab. 2).

Table 2. Percentage of bacteria of the dominant genera by season (S - spring; A - autumn) of the year $(2017,2018)$

\begin{tabular}{|l|c|c|c|c|}
\hline \multirow{2}{*}{ Genus } & \multicolumn{2}{|c|}{2017} & \multicolumn{2}{c|}{2018} \\
\cline { 2 - 5 } & $\mathrm{S}$ & $\mathrm{A}$ & $\mathrm{S}$ & $\mathrm{A}$ \\
\hline Bacillus & 6.8 & 6.8 & 3.4 & 11.2 \\
\hline Erwinia & 9.6 & 0.0 & 3.4 & 3.4 \\
\hline Pseudomonas & 20.5 & 32.9 & 2.2 & 14.6 \\
\hline Rahnella & 1.4 & 1.4 & 30.3 & 0.0 \\
\hline Serratia & 4.1 & 4.1 & 22.5 & 0.0 \\
\hline Other & 6.8 & 5.5 & 6.7 & 2.2 \\
\hline
\end{tabular}

The comparison of the variants: truffle $-\mathrm{T}$ and control - C (evaluated using the Sanger sequencing method) allowed us to distinguish three genera of bacteria. The genera Pseudomonas, Erwinia and Serratia were more abundant in the samples from T than C. Bacillus bacteria were equally numerous in both $\mathrm{T}$ and $\mathrm{C}$ samples in 2017-2018. Microbacterium and Pantoea (2017) and Methylobacterium and Viridibacillus (2018) were found only in the control samples while Brevibacterium and Acinetobacter only occurred in the truffle samples (Tab. 3). 
Table 3. Percentage of bacteria of dominant genera, indicating variant ( $\mathrm{T}$ - truffle; $\mathrm{C}$ - control) obtained by Sanger sequencing. The numbers in bold indicate the presence of a particular genus of bacteria in a particular sample

\begin{tabular}{|l|c|c|c|c|}
\hline \multirow{2}{*}{\multicolumn{1}{|c|}{ Genus }} & \multicolumn{2}{c|}{2017} & \multicolumn{2}{c|}{2018} \\
\cline { 2 - 5 } & $\mathrm{T}$ & $\mathrm{C}$ & $\mathrm{T}$ & $\mathrm{C}$ \\
\hline Bacillus & 6.8 & 6.8 & 6.7 & 7.9 \\
\hline Pseudomonas & 32.9 & 20.5 & 11.2 & 3.4 \\
\hline Erwinia & 8.2 & 1.4 & 5.6 & - \\
\hline Rahnella & - & 4.1 & 18.0 & 11.2 \\
\hline Serratia & 6.8 & 1.4 & 9.0 & 5.6 \\
\hline Brevibacterium & 1.4 & - & - & - \\
\hline Enterobacter & 1.4 & 1.4 & 1.1 & - \\
\hline Viridibacillus & 1.4 & 1.4 & - & - \\
\hline Microbacterium & - & 1.4 & - & - \\
\hline Pantoea & - & 1.4 & - & - \\
\hline Bradyrhizobium & - & - & 2.2 & - \\
\hline Acinetobacter & - & - & 1.1 & - \\
\hline Methylobacterium & - & - & - & 1.1 \\
\hline Viridibacillus & - & - & - & 1.1 \\
\hline
\end{tabular}

\section{Metagenomic analysis of DNA samples}

Alpha - biodiversity analysis

The Kruskal-Wallis statistical analysis for the indices of alpha biodiversity did not show significant differences in the values of Chao, Faith's, OTUs, Shannon's, Heip's or Simpson's indices for all the studied groups. Statistical analysis between different groups of samples for the above indices also showed no significant differences. The microbiomes for individual samples, including variants $\mathrm{T}$ and $\mathrm{C}$, did not differ significantly within individual or between groups (Tab. 4).

Analysis of beta biodiversity

Both the weighted and unweighted measures showed an unequal distribution of beta biodiversity between sample groups, as shown in Fig. 2. The GC and WC sample groups are concentrated on the right side of the plots while the remaining samples are concentrated on the left side of the plots (Fig. 2). This means that the GC and WC samples had microbiomes, which were similar to each other, and different from the microbiome of the other samples that are concentrated on the left side of the plots.

Table 4. Alpha biodiversity index values for Chao, Faith's, OTUs, Shannon's, Heip's and Simpson's indices for selected samples representing sites $\mathrm{W}, \mathrm{G}$ and $\mathrm{M}$

\begin{tabular}{|c|c|c|c|c|c|c|}
\hline Sample & Chao & Faith's & OTU & Shannon's & Heip's & Simpson's \\
\hline W1 & 188.00 & 13.77 & 188.00 & 7.12 & 0.74 & 0.99 \\
\hline $\mathrm{W} 2$ & 178.00 & 13.53 & 178.00 & 7.09 & 0.76 & 0.99 \\
\hline W4 & 362.00 & 14.56 & 362.00 & 7.78 & 0.61 & 0.99 \\
\hline W5 & 272.00 & 13.36 & 272.00 & 7.43 & 0.63 & 0.99 \\
\hline G1 & 246.00 & 13.44 & 246.00 & 7.49 & 0.73 & 0.99 \\
\hline $\mathrm{G} 2$ & 120.00 & 12.74 & 120.00 & 6.51 & 0.76 & 0.99 \\
\hline G3 & 233.00 & 15.23 & 233.00 & 7.25 & 0.65 & 0.99 \\
\hline G4 & 184.00 & 12.87 & 184.00 & 6.98 & 0.68 & 0.99 \\
\hline G5 & 239.00 & 13.73 & 239.00 & 7.46 & 0.74 & 0.99 \\
\hline G6 & 214.00 & 13.48 & 214.00 & 7.23 & 0.70 & 0.99 \\
\hline M1 & 162.00 & 12.44 & 162.00 & 6.35 & 0.50 & 0.98 \\
\hline M2 & 245.00 & 15.21 & 245.00 & 7.50 & 0.74 & 0.99 \\
\hline M3 & 252.00 & 14.80 & 252.00 & 7.53 & 0.73 & 0.99 \\
\hline M4 & 203.00 & 13.38 & 203.00 & 7.14 & 0.69 & 0.99 \\
\hline M5 & 200.00 & 13.54 & 200.00 & 7.07 & 0.67 & 0.99 \\
\hline M6 & 121.00 & 11.12 & 121.00 & 6.48 & 0.73 & 0.98 \\
\hline
\end{tabular}


A

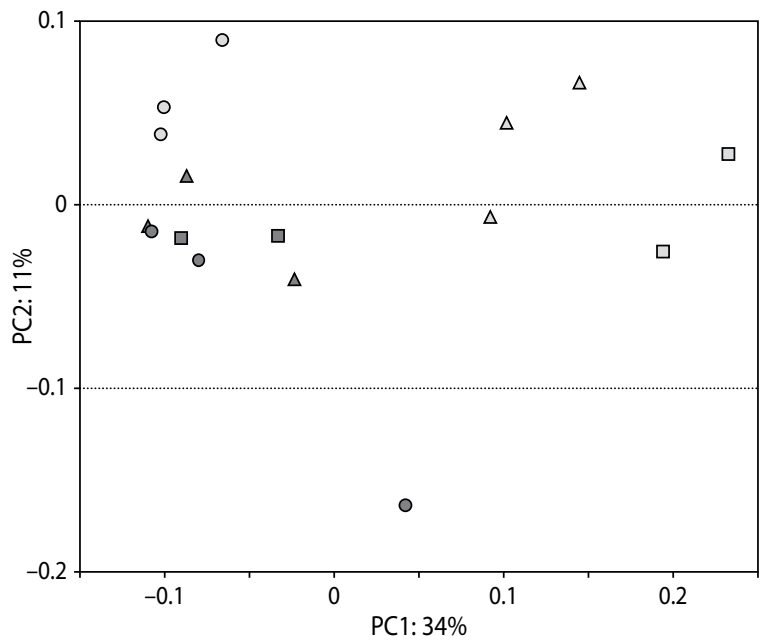

B

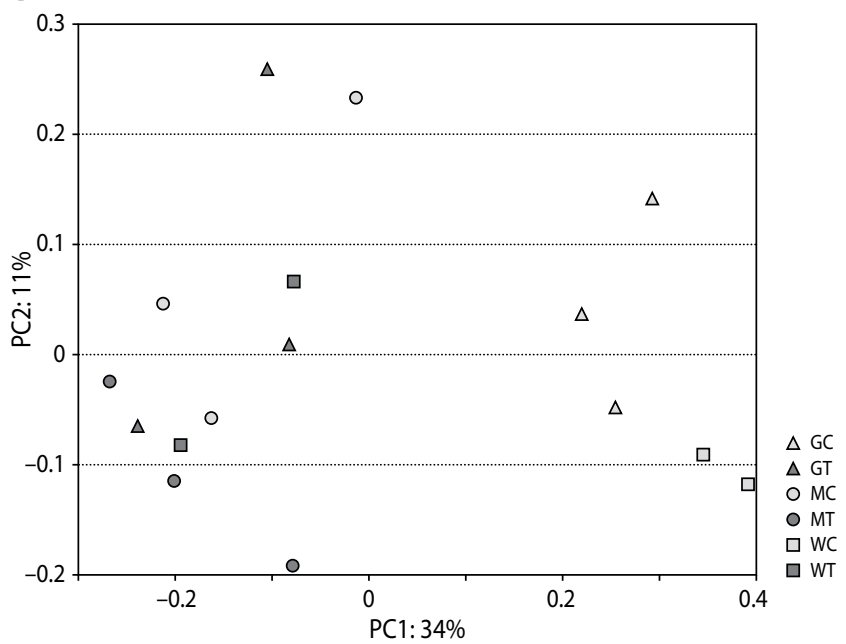

Figure 2. PcoA distance plots: A - Weighted UniFrac and B - unweighted UniFrac

Bray-Curtis dissimilarity

The value of the Bray-Curtis dissimilarity is in the range $0-1$, where 0 means that both groups have the same composition and 1 means that the groups do not have a single species in common.

The PcoA plot, which includes Bray-Curtis dissimilarity, shows the breakdown between sample groups. As with the UniFrac measures, the results of a group of WC and GC samples on the right-hand side of the plot indicate that these samples have similar microbiomes. The remaining samples concentrated on the left side of the plot differed in microbiome composition from the

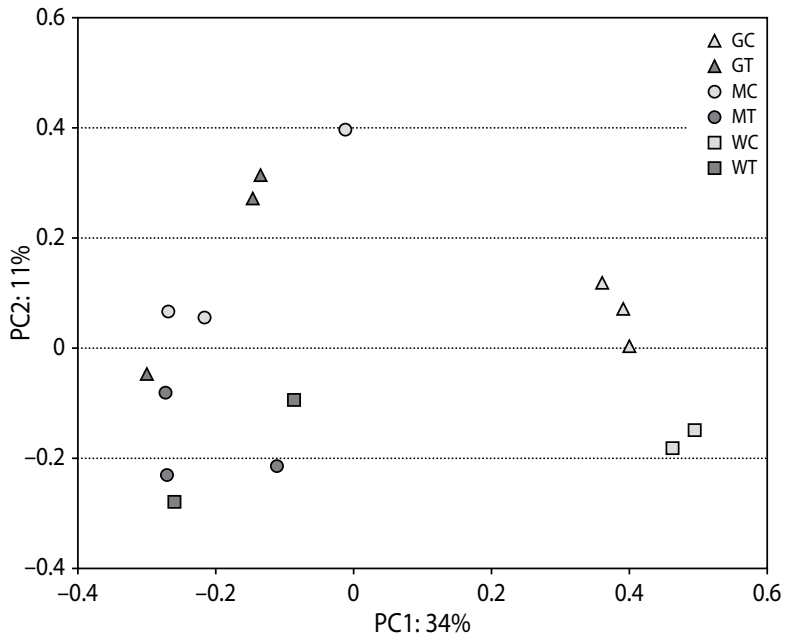

Figure 3. PcoA distance plot - Bray-Curtis dissimilarity samples concentrated on the right side of the plot. In addition, these calculations show a division between the sample groups GT and MC (upper left corner) and WT and MT (lower left corner) (Fig. 3).

Jaccard Index

The Jaccard index values, which determine the common and different elements in the sets (sample groups) in the PcoA plot, confirmed the differences between the sample groups. Similar to the UniFrac and Bray-Curtis measures, the groups of WC and GC samples were concentrated on the right side of the plot, while the remain-

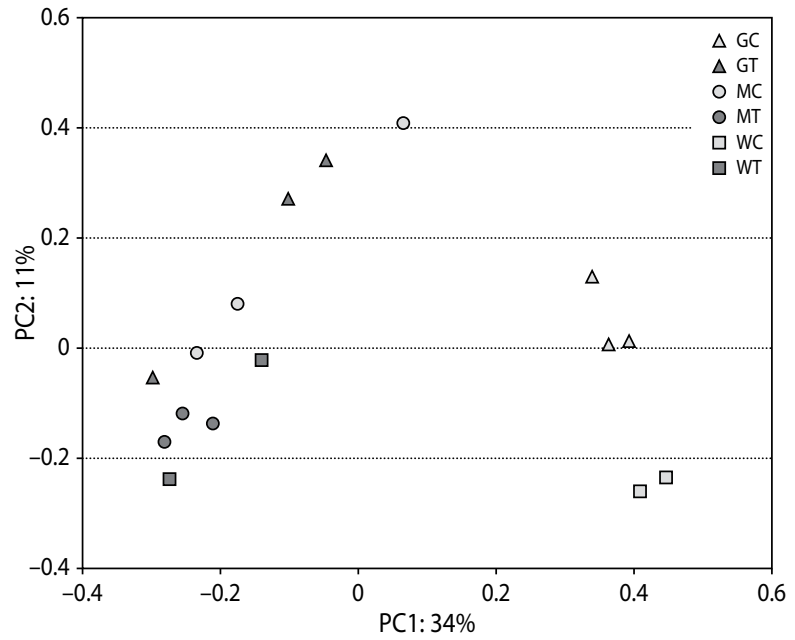

Figure 4. PcoA distance plot - Jaccard index 


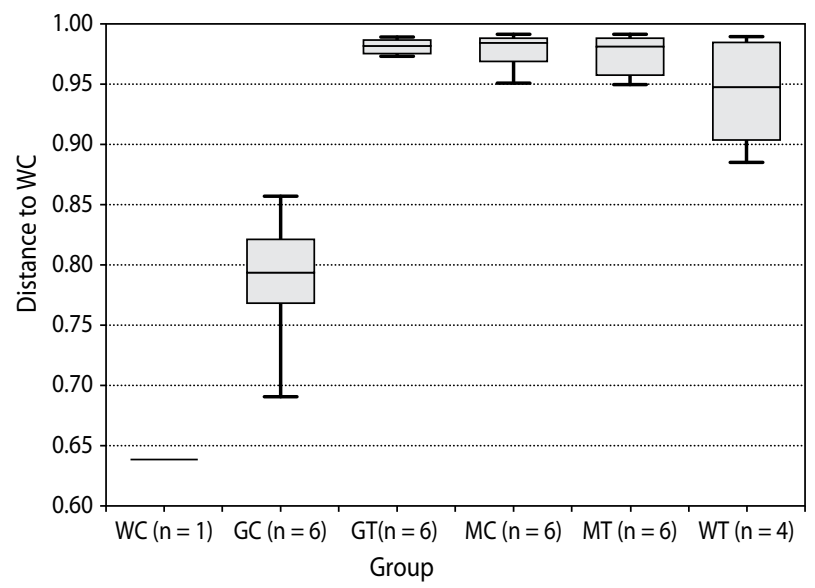

C

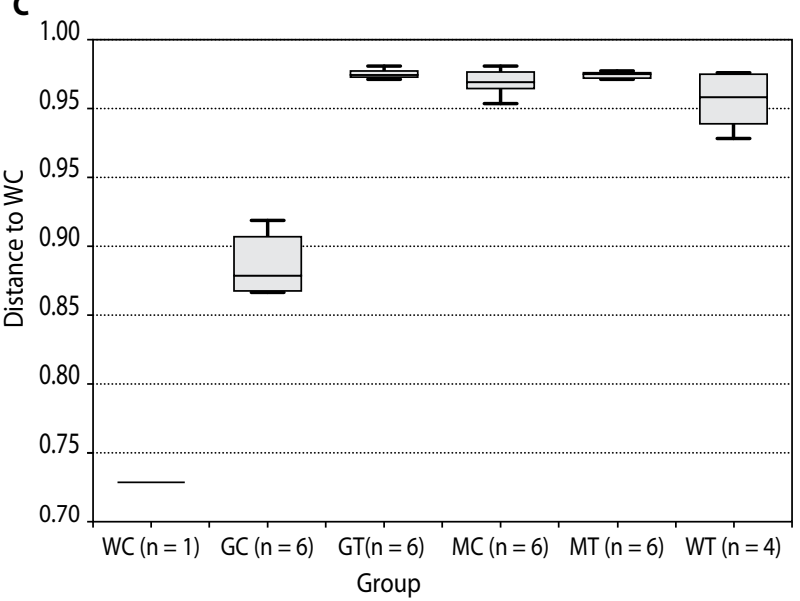

B

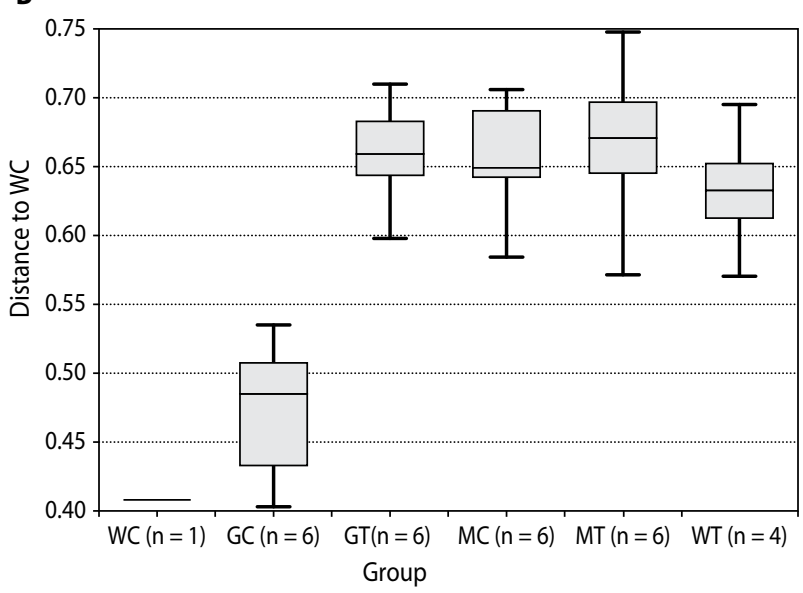

D

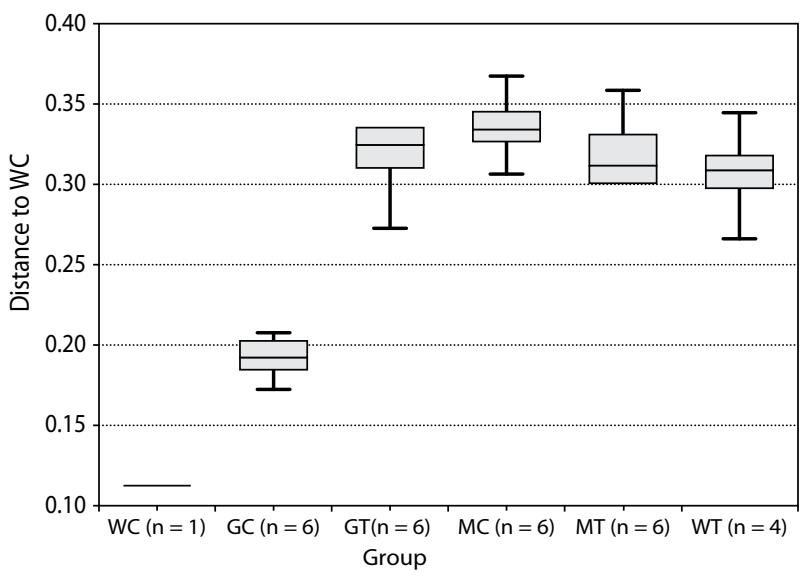

Figure 5. Boxplot charts with Bray-Curtis (A), Unweighted (B), Jaccard (C), and Weighted (D) indicators for WC sample

ing samples were on the left side of the plot. The PcoA distance plot confirms the results obtained using the Bray-Curtis dissimilarity index. In addition, both plots show the division between sample groups GT and MC (upper left corner) and WT and MT (lower left corner) (Fig. 4).

Beta biodiversity analysis - statistical analysis between sample groups

The PERMANOVA test for all the tested groups showed significant differences in the probability level $p=0.001$, therefore, the differences in distances and indicators in the analysed groups are significant.

Prepared boxplot charts with Bray-Curtis, Jaccard, Unweighted and Weighted indices show differences in the distances between the analysed groups. The value $n$ specifies the number of comparisons. Out of 12 plots made for all the indicators, differences were noted for the WC sample. For the remaining samples, no differences were observed (Fig. 5).

Analysis of alpha and beta correlations with CR coefficient values

Analysis of the alpha correlation with CR data at different time intervals showed a positive correlation relevant to Simpson's and CR coefficient in spring 2017 ( $p=0.0041, p<0.05$ ). This means that as Simpson's biodiversity increases, the $\mathrm{CR}$ index in the samples increases. In addition, a negative correlation was observed between the Shannon's index and CR value in spring 2018 ( $p=0.03, p<0.05$ ), which means that the $\mathrm{CR}$ values decrease with the increase of the index value. 
The result of the analysis also showed significance at $p<0.1$. For CR value in spring 2017, there was a positive correlation with Heip's index values $(p=0.094)$, and a negative correlation was observed between CR value in spring 2018 and values of: Chao $(p=0.073)$, Faith's $(p=0.084)$, observed OTU $(p=0.073)$ and Simspon's $(p=0.088)$ indices. Beta correlation analysis did not show any correlation between CR values at $p<0.05$. However, a positive correlation was observed between CR value in spring 2018 and Unweighted UniFrac $(p=0.054, p<0.1)$.

\section{Discussion}

The involvement, abundance, metabolic activity, and role of bacteria in shaping the forest soil environment are not yet fully understood. Bacteria in forest soils can serve many functions, including helping plants adapt to adverse conditions, that is, lack of water or excessive salinity, assisting in the formation of mycorrhizal systems, increasing the resistance of trees to stressors, and inhibiting the development of pathogens (Tsukamoto et al. 2002; Frey-Klett et al. 2007; Tarkka and Frey-Klett 2008). Soil bacteria show various endophytic and symbiotic effects on fungi, including enhancing the distribution of their spores (Citterio et al. 1995; Splivallo et al. 2015) or providing vitamins and growth regulators (Rangel-Castro et al. 2002; Riedlinger et al. 2006). Bacteria are found not only in soil and green plant tissue, but also in wood and roots (Kubiak et al., 2018). The abundance and composition of soil bacterial communities depends on the type of host plant, on the activity and nutrients of plant roots and their secretions, on fungi coexisting in the substrate, but also on climatic conditions (Bardgett 2011, Lau and Lennon 2011; Eisenhauer et al. 2017). Ambient temperature influences the number of bacteria, the ratio of bacteria to fungi, but also favourable interactions between species.

Studies by Deveau et al. (2016) in relation to T. melanosporum showed significant differences in the percentage of bacterial classes and subclass Proteobacteria in the soil on ectomycorrhizal roots during the winter months (November, December and January). Comparison of the number of OTU-level bacteria in soil and ectomycorrhizal roots and their interactions showed significant differences over time (Deveau et al. 2016).
The number of bacteria belonging to Acidobacteria, Bacteroidetes and Betaproteobacteria showed different variability depending on the time of sampling and community location - soil bacteria showed seasonally higher numbers than ectomycorrhizal root bacteria, whose communities were more stable. In the studies of Deveau et al. (2016), the number (in \%) of bacteria belonging to the class Betaproteobacteria was highest in September, and bacteria from the cluster Bacteroidetes (Microscilla) in November, compared to other dates, while the proportion of Acidobacteria (Candidatus Koribacter) increased from September to January. It was also shown that bacteria belonging to the genera Thermoleophilum and Pseudonocardia colonised ectomycorrhizal roots more frequently than soil in November. The dominant bacterial communities inhabiting ectomycorrhizal roots were bacteria belonging to the classes Alphaproteobacteria and Actinobacteria (genus Thermoleophilum).

The differences in root colonization by bacteria in the years 2017-2018 may have been due to meteorological conditions. The total precipitation in the vegetative season was $\sim 1.5$ times higher in 2017 compared to 2018. The difference between the averages of the two measuring stations was higher by $\sim 1.00$ in 2017 than in 2016 and by $\sim 2.18$ in 2017 than in 2018. From the results obtained by Siebyła and Hilszczańska (2020) on the identification of soil bacterial communities, it can be concluded that the weather conditions (here: in the autumn season of 2017) resulted in an increase in the amount of bacterial population. Similar relationships are described by Przemieniecki et al. (2021), who point to the significant influence of weather conditions at different times of the year on the activity of the bacterial microbiome in Armillaria ostoyae rhizomorphs inhabiting the roots of Scots pine trees.

The Sielianinov hydrothermal coefficient in presented research was above 2 at that time, which indicates high water saturation of the soil after the dry summer months in 2015 and 2016. In 2017, the Sielianinov hydrothermal coefficient (average of results in both stations) was $\sim 2.19$, twice as high as in 2018 when it was $\sim 1.1$.

Research by Deveau et al. (2016) concerning the analysis of ectomycorrhizal communities associated with Tuber melanosporum showed the dominance of Proteobacteria clusters, including Alphaproteobacteria $(9 \%)$, Betaproteobacteria (3\%), Deltaproteobacte- 
ria $(4 \%)$, Gammaproteobacteria $(1 \%)$, Actinobacteria $(20 \%)$, Bacteroidetes $(9 \%)$, Firmicutes $(1 \%)$, Verrucomicrobia (1\%), Acidobacteria $(0.2 \%)$ and Planctomycetes (0.4\%). Similar results to Deveau et al. (2016) were obtained by Antony-Babu et al. (2014), however, sampling was carried out in a different month and year. In this study, Proteobacteria (20.2-65.1\%) and Firmicutes (3.4-11.2\%) were the dominant groups, as was observed through the classical method (Sanger method). The use of NGS sequencing allowed us to distinguish five phyla: Proteobacteria (49\%), Actinobacteria (26\%), Bacteroidetes (11.4\%), Acidobacteria (6\%), Firmicutes (4.8\%) and others (3.3\%). A higher percentage of OTU in this study may be due to sampling of different trees, in contrast to the studies carried out by Deveau et al. (2016), where root samples were taken from C. avellana only. In this study, the alpha biodiversity index using the Shannon's index was 6.34-7.78, similar to the result obtained by Deveau et al. (2016) of 6.44-7.00. In the case of studies by Antony-Babu et al. (2014), Shannon's index was the highest, equal to 7.25. A similar difference was observed for the Chao index. In our studies, the value of the Chao index ranged from 120 (sample G2) to 362 (W4), while in the studies of Antony-Babu et al. (2014) it was as high as 10,948 .

Studies conducted by López-Mondéjar et al. (2015) and Deveau et al. (2016) indicate that the bacterial community in soil changes over time. Changes in the composition of the microbiome depending on the season may therefore affect the growth of Tuber fungi. However, the research presented here indicates that the bacterial community is affected not only by time but also by meteorological conditions, location, tree species and host plant. The results obtained by the Sanger method showed the dominance of bacteria of the genera Pseudomonas, Erwinia, Serratia, Brevibacterium and Bradyrhizobium (only in 2018), and Acinetobacter (only in 2018) in tree roots on truffle sites. The NGS sequencing gave a much more detailed picture of the bacterial communities than the Sanger sequencing for the Pseudomonas and Bradyrhizobium genera, which were only detected in the control variant. This confirms the hypothesis regarding the possibilities of practical use of the NGS method to determine the potential for truffle occurrence and, therefore, its yield.

The NGS sequencing of root samples showed differences in the proportion of Agromyces bacteria, de- pending on the variant. These studies confirm previous studies by Siebyła et al. (2020), which concerned soil analysis using Sanger sequencing. Interestingly, in the case of Lysobacter bacteria, the results of NGS sequencing of soil samples contradict the results obtained by the same method (NGS sequencing) for root samples. Studies by Siebyła et al. (unpubl.) concerning the NGS sequencing of soil samples show that there is an important positive relationship between the occurrence of Lysobacter species in soil and the presence of $T$. aestivum summer truffle ascomata. The NGS sequencing of both root and soil samples showed a negative correlation between the presence of Bradyrhizobium bacteria in the soil and the occurrence of summer truffle ascomata.

\section{Conclusions}

1. Significant differences were found between the communities determined by Sanger sequencing and NGS. Bacteria of the genus Bradyrhizobium isolated from roots with the use of Sanger sequencing were present only in the truffle variant, while NGS sequencing made it possible to show these bacteria only in the control variant.

2. Comparison of the results with previous soil studies on the same sites shows significant differences in the ratio of bacteria of a given type in the roots compared to their presence in the soil. Streptomyces bacteria were present only in roots taken from locations where summer truffles were found, while in soil, these bacteria were present in all samples regardless of the variant.

3. A negative correlation between the presence of bacteria isolated from roots of the genus Lysobacter and Bradyrhizobium and the occurrence of summer truffle ascomata was shown.

\section{ACKNOWLEDGEMENTS}

This study was carried out using the funds from the statutory activities of the Forest Research Institute, topic No. 240326/900326. I would also like to thank Mrs. Agata Młodzińska (Bioidea company) for her help and bioinformatic analysis. 


\section{RefERENCES}

Ali, N.A., Jackson, R.M. 1988. The effect of plant roots and their secretions on the germination of ectomycorrhizal fungal spores. Transactions of the British Mycological Society, 91 (2), 253-260.

Antony-Babu, S. et al. 2014. Black truffle-associated bacterial communities during the development and maturation of Tuber melanosporum ascocarps and putative functional roles. Environmental Microbiology, 16 (9), 2831-2847.

Badura, L. 2005. Mikroorganizmy glebowe i ich znaczenie w ekosystemach degradowanych przez człowieka. Inżynieria Ekologiczna, 12, 14-15.

Baldrian, P. et al. 2012. Active and total microbial communities in forest soil are largely 463 different and highly stratified during decomposition. The ISME Journal, 6, 248-258.

Bardgett, R.D. 2011. Plant-soil interactions in a changing world. F1000 Biological Reports 3, 16. DOI: 10.3410/B3-16

Beckers, B., Beeck, M.O., Weyens, N., Boerjan, W., Vangronsveld, J. 2017. Structural variability and niche differentiation in the rhizosphere and endosphere bacterial microbiome of field-grown poplar trees. Microbiome, 5, 25.

Błaszczyk, M.K. 2010. Mikrobiologia środowisk. Wydawnictwo PWN, Warszawa.

Blom, D. et al. 2011. Production of plant growth modulating volatiles is widespread among rhizosphere bacteria and strongly depends on culture conditions. Environmental Microbiology, 13, 3047-3058.

Boersma, F.G.H., Warmink, J.A., Andreote, F.A., Van Elsas, J.D. 2009. Selection of Sphingomonadaceae at the base of Laccaria proxima and Russula exalbicans fruiting bodies. Applied and Environmental Microbiology, 75, 1979-1989.

Boersma, F.G.H., Otten, R., Warmink, J.A., Nazir, R., Van Elsas, J.D. 2010. Selection of Variovorax paradoxus-like bacteria in the mycosphere and the role of fungal-released compounds. Soil Biology and Biochemistry, 42 (12), 2137-2145.

Citterio, B. et al. 1995. Isolation of bacteria from sporocarps of Tuber magnatum Pico, Tuber borchii Vitt. and Tuber maculatum Vitt. In: Biotechnology of ectomycorrhizae, (eds.: V. Stocchi, P. Bonfante, M. Nuti). Plenum Press, New York, 241-248.
Clark, D.S. 1971. Studies on the surface plate method of counting bacteria. Canadian Journal of Microbiology, 17 (7), 943-946.

Deveau, A. et al. 2007. The mycorrhiza assistant Pseudomonas fluorescens BBc6R8 has a specific stimulating effect on the growth, morphology and expression of the genes of the ectomycorrhizal fungus Laccaria bicolor S238N. New Phytologist, 175 (4), 743-755.

Deveau, A. et al. 2016. Temporal changes of bacterial communities in the Tuber melanosporum ectomycorrhizosphere during ascocarp development. $\mathrm{Myc}$ orrhiza, 26, 389-399.

Eisenhauer, N. et al. 2017. The root biomass and secretions combine the diversity of plants with the biomass of soil bacteria and fungi. Scientific Reports, 7 (1), 1-8.

Foster, R.C. 1988. Microenvironments of soil microorganisms. Biology and Soil Fertility, 6 (3), 189-203.

Frey-Klett, P., Garbaye, J.A., Tarkka, M. 2007. The mycorrhiza helper bacteria revisited. New Phytologist, 176, 22-36.

Frey-Klett, P., Burlinson, P., Deveau, A., Barret, M., Tarkka, M., Sarniguet, A. 2011. Bacterico-fungal interactions: links between agricultural, clinical, environmental and food microbiologists. Review of Microbiology and Molecular Biology, 75 (4), 583-609.

Galus-Barchan, A., Paśmionka, I. 2014. The occurrence of selected microorganisms in the soil in the area of the Niepolomice Forest with particular emphasis on mould fungi. Polish Journal of Agronomy, 17, $11-17$.

Gotkowska-Płachta, A., Filipkowska, Z., Korzeniewska, E., Janczukowicz, W. 2008. Microbiological contamination of the atmospheric air in and around the sewage treatment plant with an overhead pond system. Water-Environment-Rural Areas, 8, 83-98.

Gryndler, M., Hršelová, H. 2012. Isolation of bacteria from ectomycorrhizae of Tuber aestivum Vittad. Acta Mycologica, 47, 155-160.

Gryndler, M. et al. 2013. A quest for indigenous truffle helper prokaryotes. Environmental Microbiology Reports, 5, 346-352.

Hilszczańska, D. 2016. Polskie trufle skarb odzyskany. Centrum Informacyjne Lasów Państwowych, Warsaw, Poland. 
Hilszczańska, D., Szmidla, H., Sikora, K., Rosa-Gruszecka, A. 2019. Soil properties conducive to the formation of Tuber aestivum Vitt. fruiting bodies. Polish Journal of Environmental Studies, 28, 1713-1718.

Kubiak, K., Wrzosek, M., Przemieniecki, S., Damszel, M., Sierota, Z. 2018. Bacteria inhabiting wood of roots and stumps in forest and arable soils. In: Endophytes of forest trees. Springer, Cham, 319-342.

Kurek, E., Kobus, J. 1990. Beneficial and harmful influence of rhizosphere microflora on the growth and development of plants. Advances in Microbiology, 29, 103-123.

Kim, Bo-Ra et al. 2017. Deciphering diversity indices for a better understanding of microbial communities. Journal of Microbiology and Biotechnology, 27, 2089-2093.

Kubiak, K., Damszel, M., Sikora, K., Przemieniecki, S., Małecka, M., Sierota, Z. 2017. Colonization of fungi and bacteria in stumps and roots of scots pine after thinning and treatment with Rotstop. Journal of Phytopathology, 165, 143-156.

Lane, D.J. 1991. 16S/23S rRNA sequencing. In: Nucleic acid techniques in bacterial systematics (eds.: E. Stackebrandt, M. Goodfellow). John Wiley and Sons, 115-175.

López-Mondéjar, R., Voříšková, J., Větrovský, T., Baldrian, P. 2015. The bacterial community of the temperate zone deciduous forests is vertically stratified and subject to seasonal dynamics. Soil Biology and Biochemistry, 87, 43-50.

Lau, J.A., Lennon, J.T. 2011. Evolutionary ecology of plant-microbe interactions: soil microbial structure alters selection on plant traits. New Phytologist, 192 (1), 215-224.

Lozupone, C., Knight, R. 2005. UniFrac: a new phylogenetic method for comparing microbial communities. Applied and Environmental Microbiology, 71.12, 8228-8235.

Medinger, R. et al. 2010. Diversity in a hidden world: potential and limitation of next-generation sequencing for surveys of molecular diversity of eukaryotic microorganisms. Molecular Ecology, 19, 32-40.

Mello, A. et al. 2013. Truffle brûlés have an impact on the diversity of soil bacterial communities. PLoS One, 8 (4), 61945.
Ncbi. Available at http://www.ncbi.nlm.nih.gov/ (access on 15 November 2017).

Pociejowska, M., Natywa, M., Gałązka, A. 2014. Stymulacja wzrostu roślin przez bakterie PGPR. Kosmos, 4, 603-610.

Poole, E.J., Bending, G.D., Whipps, J.M., Read, D.J. 2001. Bacteria associated with Pinus sylvestrisLactarius rufus ectomycorrhizas and their effects on mycorrhiza formation in vitro. New Phytologist, 151 (3), 743-751.

Proença, D.N. et al. 2017. Microbial endophytic, wood colonizing pine bacteria as a result of pine wilting disease. Scientific Reports, 7 (1), 1-9.

Przemieniecki, S.W. et al. 2021. Bacterial microbiome in Armillaria ostoyae rhizomorphs inhabiting the root zone during progressively dying Scots pine. Applied Soil Ecology, 164, 103929. DOI: https://doi. org/10.1016/j.apsoil.2021.103929

Rangel-Castro, I.J., Danell, E., Taylor, A.F. 2002. Use of different nitrogen sources by the edible ectomycorrhizal mushroom Cantharellus cibarius. Mycorrhiza, 12 (3), 131-137.

Riedlinger, J., Schrey, S.D., Tarkka, M.T., Hampp, R., Kapur, M., Fiedler, H.P. 2006. Auxofuran, a novel metabolite that stimulates the growth of fly agaric, is produced by the mycorrhiza helper bacterium Streptomyces strain AcH 505. Applied and Environmental Microbiology, 72 (5), 3550-3557.

Rosa-Gruszecka, A., Hilszczańska, D., Szmidla, H. 2014. Warunki środowiskowe sprzyjające występowaniu trufli (Tuber spp.) na historycznych stanowiskach w Polsce. Leśne Prace Badawcze, 75, 5-11.

Siebyła, M., Hilszczańska, D. 2020. Diversity of soil bacteria complexes associated with summer truffle (Tuber aestivum). Folia Forestalia Polonica, Series $A$ - Forestry, 62 (2), 114-127. DOI: 10.2478/ffp2020-0012

Siebyła, M., Hilszczańska, D. Genomic analysis (Next Generation Sequencing) of bacteria in the soils of sites of naturally-occurring summer truffle (Tuber aestivum Vittad.). unpubl.

Splivallo, R., Deveau, A., Valdez, N., Kirchhoff, N., Frey-Klett, P., Karlovsky, P. 2015. Bacteria associated with truffle-fruiting bodies contribute to truffle aroma. Environmental Microbiology, 17 (8), 2647-2660. 
Sosnowski, J., Król, J. 2018. Effect of synthetic plant hormones on the concentration of $\mathrm{Ca}, \mathrm{Mg}$ and $\mathrm{K}$ in Medicago x varia T biomass. Martyn and Trifolium pratense L. Annual Set the Environment Protection Environmental Protection, 20, 1465-1479.

Staley, C. et al. 2013. Application of Illumina nextgeneration sequencing to characterize the bacterial community of the Upper Mississippi River. Journal of Applied Microbiology, 115 (5), 1147-1158.

Steinauer, K., Chatzinotas, A., Eisenhauer, N. 2016. Cocktails with root exudation: a link between plant diversity and soil microorganisms? Ecology and Evolution, 6 (20), 7387-7396.

Sun, L., Qiu, F., Zhang, X., Daim, X., Dong, X., Song, W. 2008. Endophytic bacterial diversity in rice (Oryza sativa L.) roots estimated by $16 \mathrm{~S}$ rDNA sequence analysis. Microbial Ecology, 55 (3), 415-424.

Tarkka, M.T., Frey-Klett, P. 2008. Mycorrhiza helper bacteria. In: Mycorrhiza (ed.: A. Varma). Springer, Berlin, Heidelberg. DOI: https://doi. org/10.1007/978-3-540-78826-3_6

Tedersoo, L. et al. 2010. 454 Pyrosequencing and Sanger sequencing of tropical mycorrhizal fungi provide similar results but reveal substantial methodological biases. New Phytologist, 188 (1), 291-301.

Team, R.C. 2013. A language and environment for statistical computing.

Tsukamoto, T., Murata, H., Shirata, A. 2002. Identification of non-pseudomonad bacteria from fruit bodies of wild agaricales fungi that detoxify tolaasin produced by Pseudomonas tolaasii. Bioscience, Biotechnology, and Biochemistry, 66 (10), 2201-2208.

Vahdatzadeh, M., Deveau, A., Splivallo, R. 2015. The role of the microbiome of truffles in aroma formation: a meta-analysis approach. Applied and Environmental Microbiology, 81, 6946-6952.

Zacchi, L., Vaughan-Martini, A., Angelini, P. 2003. Yeast distribution in a truffle field ecosystem. Annals of Microbiology, 53, 275-282.

\section{ApPeNDix}

Number of OTU units of the dominant types of bacteria including variant ( $\mathrm{T}$ - truffle; $\mathrm{C}$ - control) using NGS sequencing. The numbers in bold indicate the presence of a particular genus of bacteria in a particular variant.

\begin{tabular}{|c|c|c|}
\hline \multirow{2}{*}{ OTU ID (genus) } & \multicolumn{2}{|c|}{ VARIANT } \\
\hline & $\mathrm{T}$ & $\mathrm{C}$ \\
\hline 1 & 2 & 3 \\
\hline Acidicapsa & 0 & 834 \\
\hline Acidipila & 0 & 1813 \\
\hline Acidisphaera & 0 & 1306 \\
\hline Acidobacterium & 0 & 759 \\
\hline Acidocella & 0 & 35 \\
\hline Acidothermus & 0 & 184 \\
\hline Acidovorax & 0 & 60 \\
\hline Actinoallomurus & 0 & 117 \\
\hline Actinocrinis & 0 & 473 \\
\hline Actinokineospora & 0 & 79 \\
\hline Actinospica & 0 & 717 \\
\hline Actinosynnema & 0 & 206 \\
\hline Afipia & 262 & 0 \\
\hline Agromyces & 90 & 0 \\
\hline Albimonas & 29 & 0 \\
\hline Aliidongia & 0 & 955 \\
\hline Allokutzneria & 0 & 54 \\
\hline Alteromonas & 37 & 0 \\
\hline Amaricoccus & 55 & 0 \\
\hline Angustibacter & 0 & 296 \\
\hline Arcobacter & 38 & 0 \\
\hline Asaia & 48 & 0 \\
\hline Azoarcus & 54 & 0 \\
\hline Azospirillum & 0 & 39 \\
\hline Bacillus & 31 & 0 \\
\hline Baekduia & 145 & 0 \\
\hline Bauldia & 25 & 0 \\
\hline Bdellovibrio & 0 & 32 \\
\hline Blastococcus & 76 & 0 \\
\hline Blastomonas & 0 & 87 \\
\hline Bradyrhizobium & 0 & 153 \\
\hline Brumimicrobium & 0 & 83 \\
\hline Bryobacter & 0 & 297 \\
\hline Bryocella & 0 & 112 \\
\hline Caenimonas & 76 & 0 \\
\hline Caldicellulosiruptor & 0 & 102 \\
\hline Calditerricola & 0 & 14 \\
\hline Catelliglobosispora & 0 & 69 \\
\hline Catenulispora & 0 & 308 \\
\hline Chelativorans & 129 & 0 \\
\hline Chitinophaga & 302 & 0 \\
\hline Chondromyces & 22 & 0 \\
\hline Collimonas & 0 & 41 \\
\hline Conexibacter & 0 & 333 \\
\hline Denitratisoma & 71 & 0 \\
\hline Desulfonatronum & 171 & 0 \\
\hline Desulfuromonas & 280 & 0 \\
\hline
\end{tabular}




\begin{tabular}{|c|c|c|}
\hline 1 & 2 & 3 \\
\hline Devosia & 0 & 246 \\
\hline Dinghuibacter & 0 & 19 \\
\hline Dokdonella & 0 & 39 \\
\hline Dyadobacter & 0 & 28 \\
\hline Elioraea & 0 & 37 \\
\hline Erythrobacter & 91 & 0 \\
\hline Ferrimicrobium & 317 & 0 \\
\hline Ferruginibacter & 213 & 0 \\
\hline Fibrobacter & 45 & 0 \\
\hline Flavitalea & 0 & 127 \\
\hline Frigoribacterium & 0 & 35 \\
\hline Goodfellowiella & 0 & 151 \\
\hline Granulicella & 0 & 2639 \\
\hline Haliangium & 70 & 0 \\
\hline Hartmannibacter & 35 & 0 \\
\hline Helicobacter & 337 & 0 \\
\hline Herbaspirillum & 0 & 22 \\
\hline Ideonella & 47 & 0 \\
\hline Inquilinus & 0 & 24 \\
\hline Jatrophihabitans & 0 & 175 \\
\hline Jiangella & 253 & 0 \\
\hline Kaistibacter & 0 & 166 \\
\hline Kineosporia & 0 & 126 \\
\hline Kofleria & 37 & 0 \\
\hline Krasilnikovia & 246 & 0 \\
\hline Kutzneria & 0 & 92 \\
\hline Labedaea & 0 & 173 \\
\hline Lentzea & 306 & 0 \\
\hline Leptothrix & 0 & 265 \\
\hline Lewinella & 159 & 0 \\
\hline Lysobacter & 0 & 282 \\
\hline Marmoricola & 0 & 37 \\
\hline Mesorhizobium & 256 & 0 \\
\hline Methylobrevis & 66 & 0 \\
\hline Methyloceanibacter & 556 & 0 \\
\hline Methylosinus & 0 & 103 \\
\hline Methylotenera & 2469 & 0 \\
\hline Microcystis & 211 & 0 \\
\hline Mycobacterium & 0 & 107 \\
\hline Nakamurella & 63 & 0 \\
\hline Natranaerovirga & 74 & 0 \\
\hline Niabella & 211 & 0 \\
\hline Niameybacter & 0 & 108 \\
\hline Niastella & 475 & 0 \\
\hline Nitratifractor & 0 & 173 \\
\hline Nitrosospira & 813 & 0 \\
\hline Nonomuraea & 0 & 65 \\
\hline Occallatibacter & 0 & 249 \\
\hline
\end{tabular}

\begin{tabular}{|c|c|c|}
\hline 1 & 2 & 3 \\
\hline Paludibaculum & 0 & 2367 \\
\hline Parasegetibacter & 194 & 0 \\
\hline Pedobacter & 0 & 126 \\
\hline Pelomonas & 83 & 0 \\
\hline Phaselicystis & 84 & 0 \\
\hline Phycicoccus & 0 & 31 \\
\hline Phytomonospora & 214 & 0 \\
\hline Piscinibacter & 86 & 0 \\
\hline Plantactinospora & 353 & 0 \\
\hline Polaromonas & 57 & 0 \\
\hline Promicromonospora & 138 & 0 \\
\hline Providencia & 55 & 0 \\
\hline Pseudomonas & 0 & 28 \\
\hline Pseudonocardia & 0 & 379 \\
\hline Pseudoxanthobacter & 0 & 56 \\
\hline Puia & 0 & 508 \\
\hline Reyranella & 0 & 86 \\
\hline Rhizocola & 20 & 0 \\
\hline Rhizomicrobium & 0 & 651 \\
\hline Rhizorhabdus & 2505 & 0 \\
\hline Rhodanobacter & 0 & 75 \\
\hline Rhodoferax & 329 & 0 \\
\hline Rhodomicrobium & 375 & 0 \\
\hline Rhodopila & 0 & 26 \\
\hline Rhodoplanes & 148 & 0 \\
\hline Rhodopseudomonas & 0 & 440 \\
\hline Roseiarcus & 0 & 3935 \\
\hline Rubrivivax & 0 & 49 \\
\hline Saccharomonospora & 128 & 0 \\
\hline Salinispora & 90 & 0 \\
\hline Skermanella & 0 & 165 \\
\hline Solirubrobacter & 0 & 654 \\
\hline Sorangium & 30 & 0 \\
\hline Sphingobacterium & 391 & 0 \\
\hline Sphingomonas & 838 & 0 \\
\hline Stenotrophomonas & 0 & 18 \\
\hline Steroidobacter & 0 & 143 \\
\hline Streptacidiphilus & 0 & 494 \\
\hline Streptomyces & 683 & 0 \\
\hline Sulfurisoma & 200 & 0 \\
\hline Tabrizicola & 90 & 0 \\
\hline Telmatobacter & 0 & 5097 \\
\hline Terracidiphilus & 0 & 448 \\
\hline Terriglobus & 0 & 83 \\
\hline Thermocatellispora & 0 & 85 \\
\hline Uliginosibacterium & 51 & 0 \\
\hline Umezawaea & 207 & 0 \\
\hline Virgisporangium & 49 & 0 \\
\hline
\end{tabular}

